\title{
Effects of salinity on growth and metabolism in blue tilapia (Oreochromis aureus)
}

\author{
Semra Küçük ${ }^{1 *}$, Aslihan Karul ${ }^{2}$, Şükrü Yildirim ${ }^{3}$ and Kutsal Gamsiz ${ }^{3}$ \\ ${ }^{1}$ Department of Fisheries, Faculty of Agriculture, Adnan Menderes University, 09100, Aydin, Turkey. \\ ${ }^{2}$ Department of Biochemistry, Faculty of Medicine, Adnan Menderes University, 09100, Aydin, Turkey. \\ ${ }^{3}$ Department of Aquaculture, Faculty of Fisheries, Aegean University, 35100, Bornova, İmir, Turkey.
}

Accepted 13 June, 2012

\begin{abstract}
Tilapia were acclimated to the water source which had 8 precipitation (ppt) of salinity in the experimental unit before the experiment started and then, they were transfered to five different saltwater (SW) treatments: SW (8 ppt), 50\% SW (12 ppt), 100\% SW (16 ppt), $150 \%$ SW (20 ppt), and $200 \%$ SW (24 ppt). The objectives of this study were; to investigate the effects of five different salinities on specific growth rate (SGR), weight gain (WG), food intake (FI) and survival of tilapia in the long term trial (30 days) and find out how salinity affects muscle water content, hematosomatic index (HSI), and blood chemistry (sodium, chloride, potassium, glucose, total protein and triglycerides) in the short term trial (6 to $12 \mathrm{~h}$ ). In the long-term trial, six fish were stocked in each aquarium. They were fed with commercial feed (Bagcı trout) to satiation twice a day and individually weighed at ten-days interval. Growth rate was highest in the $50 \%$ SW (SGR $0.95 \pm 0.18 \%$ per day); there was no significant difference among the first three treatments. Growth rate was lowest in $200 \%$ SW (SGR $0.23 \pm 0.08 \%$ per day). Weight gain and food intake showed identical results as SGR. Survival was high in the first three groups $(72.2 \pm 19.2$ to 100.0 \pm 0.0 ) but it was lowest in the $200 \%$ SW treatment $(22.2 \pm 19.2 \%)$. In the short-term trial, six tilapia were placed per aquarium. They were exposed to SW, 50, 100, 150 and $200 \%$ SW treatments and the fish were gradually acclimated to salt water. Blood samples were taken to analyse plasma sodium, chloride, potassium, total protein and triglycerides. Liver and muscle samples were collected for HSI and moisture values. Plasma sodium chloride increased in parallel with salinity rise. Total protein and triglycerides significantly reduced as salinity increased. Glucose and potassium were not altered significantly. HSI and muscle water content decreased when salinity concentration was elevated. Blood chemistry demonstrated that isosmotic water concentration was between 8 and 12 ppt. Salinity did not affect HSI and moisture until it reached as much as 16 ppt $(100 \% \mathrm{SW})$. The results show that the optimum condition for farming blue tilapia, Oreochromis aureus, both with respect to growth rate and metabolic parameters is at salinities lower than 12 ppt. This is an important finding for the tilapia industry.
\end{abstract}

Key words: Tilapia, salinity, growth, survival, metabolism.

\section{INTRODUCTION}

Tilapia is a fresh water species most widely cultured in the world. Production of tilapia is 2.5 million tons (FAO, 2007). The first five orders of the most produced countries are China, Egypt, Endonesia, Thailand and Philippines, respectively. The first three orders of the most imported countries are USA, European Union and Japan, respectively. Tilapia is the general name of cichlids. They are taxanomically classified in the family of Cichlidae of order Perciformes. Its origin is Africa. There are three genera, Oreochromis, Sarotherodon and Tilapia 
Table 1. Water quality parameters of source.

\begin{tabular}{lc}
\hline Parameter & Value \\
\hline $\mathrm{EC}(\mu \mathrm{s} / \mathrm{cm})$ & 842.2 \\
Total hardness $\left(\mathrm{mg} / \mathrm{L} \mathrm{CaCO}_{3}\right)$ & 732.5 \\
Alkalinity $(\mathrm{mg} / \mathrm{l} \mathrm{CaCO}$ & $3)$ \\
Bicarbonat $(\mathrm{mg} / \mathrm{L})$ & 600.0 \\
Calcium $(\mathrm{mg} / \mathrm{L})$ & 348.9 \\
Magnesium $(\mathrm{mg} / \mathrm{L})$ & 89.8 \\
Ammonia $(\mathrm{mg} / \mathrm{L})$ & 12.4 \\
Nitrite $(\mathrm{mg} / \mathrm{L})$ & 0.22 \\
\hline
\end{tabular}

in this family. The most distinguishable characteristic in them is reproductive behavior. Tilapia species are nest builders. Oreochromis and Sarotherodon are mouth brooders.

Since approximately 60 years, tilapia has been cultured in the tropical and subtropical regions. Nowadays, the most commercially cultured genus of tilapia is Oreochromis and more than $90 \%$ of all is Nile tilapia in the world. The most farmed species of them are Nile tilapia (Oreochromis niloticus), Blue tilapia (Oreochromis aureus), Mozambique tilapia (Oreochromis mossambicus) and Zanzibar tilapia (Oreochromis hornorum) (Popma and Masser, 1999). Salinity is described as the sum of all ions in water. It consists of not only sodium and chloride, but also calcium, magnesium, potassium, bicarbonate, and sulfate ions. If salinity is so low (for example, fresh water), it can be expressed in milligram per liter (ppm). If it is so high (for example, brackish water and sea), it can be defined as parts per thousand (ppt) (Boyd, 1990; Boyd and Tucker, 1998).

In aquaculture, not only quality and quantity of feed are important, but also adequate environmental conditions is vital for fish production. Salinity is one of the important abiotic environmental factors (temperature, dissolved oxygen) that direct fish growth (Mommsen, 1998). When fish are forced to deal with different salinities, depending on marine or fresh water fish, they spend more energy to hold their homeostasis and grow less. Because osmoregulation break down, fish spends more energy to hold sodium and chloride ions in their bodies or take off them. The aim of this study was to assess the influences of five different salinity treatments (SW, 50, 100, 150, and $200 \%$ SW) on growth (specific growth rate, weight gain, food intake and survival), blood chemistry (sodium, chloride, potassium, glucose, total protein and triglycerides) and metabolic parameters (hematosomatic index, and muscle water content).

\section{MATERIALS AND METHODS}

\section{Long-term effects of salinity on fish}

Tilapia $(\mathrm{n}=90,26.04 \pm 3.70 \mathrm{~g}$ bw and $118.13 \pm 6.90 \mathrm{~mm}$ bl) were provided commercially and acclimated to laboratory conditions (8 ppt water source and about $25^{\circ} \mathrm{C}$ ) for one month before the experiment started. Salinity was gradually raised to the desired salinity levels (2 ppt per day). Laboratory condition was climatized for $24 \mathrm{~h}$ a day to constrict water temperature to around 25 to $26{ }^{\circ} \mathrm{C}$. Water quality parameters $[\mathrm{pH}$, temperature, electrical conductivity (EC), total hardness, alkalinity, bicarbonate, calcium, magnesium, ammonia and nitrite] were measured and are given in Table 1. The osmolarity of each salinity treatment was measured by osmometer (Model 3250 Advenced Instruments, Inc). Six fishes were placed in the $20 \mathrm{~L}$ aquariums for each salinity treatment. Fish were not fed for $24 \mathrm{~h}$ before stocking each aquarium. Fish was fed ad libitum with commercial feed (Bagcı trout, $45 \%$ protein, $21 \%$ fat) twice a day for 30 days. There were three replicates per salinity level. In each aquarium, water was renewed every morning at the rate of $50 \%$ with fresh water having similar salinities. Fish were weighed individually on day $0,10,20$ and 30 . Fish growth (specific growth rate, weight gain, food intake) and survival were calculated (Kangombe and Brown, 2008).

Specific growth rate $(S G R)\left(\%\right.$ day $\left.^{-1}\right)=\left[\left(\log _{e} W_{f}-\log _{e} W_{i}\right) /\right.$ day $] x$ 100

Food intake $(\mathrm{FI})(\mathrm{g})=$ total feed consumption

Weight gain $(W G)(g)=W_{f}-W_{i}$

Survival (S) $(\%)=\left(\left(\mathrm{N}_{\mathrm{f}}-\mathrm{N}_{\mathrm{i}}\right) / \mathrm{N}_{\mathrm{i}}\right) \times 100$

Where, $W_{i}$ and $W_{f}$ are the initial and final mean body weights and $\mathrm{N}_{\mathrm{f}}, \mathrm{N}_{\mathrm{i}}$ are the numbers of harvested and stocked fish.

\section{Short-term effects of salinity on fish}

Tilapia $(\mathrm{n}=60,47.53 \pm 6.54 \mathrm{~g} \mathrm{bw}$ and $147.03 \pm 8.53 \mathrm{~mm}$ bl) were exposed to five different salinities (SW, 50, 100, 150 and $200 \%$ $\mathrm{SW}$ ). Fish were separately placed in the $20 \mathrm{~L}$ aquariums (6 fish per aquarium) for each treatment. Two replicates were used for each treatment. They were fed ad libitum with commercial feed (Bagcl trout, $45 \%$ protein, $21 \%$ fat) twice a day. Salinity was gradually raised to 2 ppt per day until desired salinity levels were reached. Three fishes were removed from each aquarium for blood sampling (six samples for each salinity treatments). Fish total length (the nearest $\mathrm{mm}$ ) and fresh weight (to the nearest $\mathrm{mg}$ ) were measured, and blood samples ( 1 to $2 \mathrm{ml}$ ) were immediately taken from caudal vein by vacutainer tubes ( $2 \mathrm{ml}$, without anticoagulant, BD brand) and needles $(0.7 \times 38 \mathrm{~mm}$, BD brand). Samples were kept on ice before being centrifuged for $5 \mathrm{~min}$ at $6000 \mathrm{rpm}$. Plasma was stored at $-80^{\circ} \mathrm{C}$ until analysis was performed. Plasma sodium, chloride, potassium, glucose, total protein and triglycerides were analysed in blood by autoanalyzor machine (Architect C8000). For muscle tissue samples ( 1 to $2 \mathrm{~g}$ ) without skin, scan were taken from the dorsal region to determine water content. They were weighed to the nearest milligram immediately after removal. They were dried at $80^{\circ} \mathrm{C}$ for $24 \mathrm{~h}$ and reweighed every $24 \mathrm{~h}$ until constant weight was found. Total liver was removed and freshly weighed for hepatosomatic index. Muscle water content and hematosomatic index were verified (Luz et al., 2008; Overton et al., 2008).

Muscle moisture $(\%)=[$ (wet weight-dry weight $) /$ wet weight $] \times 100$

Hepatosomatic index (HSI) $(\%)=($ wet liver weight/body weight) $x$ 100

Differeces in mean values of SGR, WG, FI, survival, HSI, muscle moisture and blood parameters among each treatment were analyzed by SSPS (18.0). Differences between the means were 
Table 2. Water $\mathrm{pH}$, temperature and osmolality at five different salinities (mean $\pm \mathrm{SD}$ ).

\begin{tabular}{lccccc}
\hline Salinity & SW & $\mathbf{5 0} \%$ SW & $\mathbf{1 0 0 \% ~ S W}$ & $\mathbf{1 5 0 \% ~ S W}$ & $\mathbf{2 0 0 \% ~ S W ~}$ \\
\hline $\mathrm{pH}$ & $7.72 \pm 0.26^{\mathrm{a}}$ & $7.69 \pm 0.24^{\mathrm{a}}$ & $7.71 \pm 0.22^{\mathrm{a}}$ & $7.66 \pm 0.20^{\mathrm{a}}$ & $7.60 \pm 0.19^{\mathrm{a}}$ \\
Temperature $\left({ }^{\circ} \mathrm{C}\right)$ & $26.13 \pm 0.73^{\mathrm{a}}$ & $25.78 \pm 0.95^{\mathrm{a}}$ & $25.70 \pm 0.69^{\mathrm{a}}$ & $25.80 \pm 0.58^{\mathrm{a}}$ & $26.13 \pm 0.38^{\mathrm{a}}$ \\
Osmolarity $(\mathrm{mOsm} / \mathrm{kg})$ & $24.50 \pm 1.00^{\mathrm{a}}$ & $149.00 \pm 0.82^{\mathrm{b}}$ & $275.75 \pm 1.26^{\mathrm{c}}$ & $401.50 \pm 0.58^{\mathrm{d}}$ & $535.34 \pm 0.77^{\mathrm{e}}$ \\
\hline
\end{tabular}

Table 3. The effect of salinity on specific growth rate (SGR), weight gain, food intake and survival of tilapia (mean \pm SD) for 30 days.

\begin{tabular}{ccccc}
\hline Salinity & SGR (\%/day) & Weight gain (g) & Food intake (g) & Survival (\%) \\
\hline SW & $0.70 \pm 0.01^{\mathrm{a}}$ & $6.02 \pm 0.44^{\mathrm{a}}$ & $13.76 \pm 2.65^{\mathrm{b}}$ & $94.4 \pm 9.6^{\mathrm{a}}$ \\
$50 \%$ SW & $0.95 \pm 0.18^{\mathrm{a}}$ & $8.35 \pm 0.85^{\mathrm{a}}$ & $20.82 \pm 2.78^{\mathrm{a}}$ & $100.0 \pm 0.0^{\mathrm{a}}$ \\
$100 \%$ SW & $0.84 \pm 0.09^{\mathrm{a}}$ & $7.46 \pm 1.16^{\mathrm{a}}$ & $14.30 \pm 5.29^{\mathrm{b}}$ & $72.2 \pm 19.2^{\mathrm{a}}$ \\
$150 \%$ SW & $0.81 \pm 0.30^{\mathrm{a}}$ & $7.49 \pm 3.39^{\mathrm{a}}$ & $14.38 \pm 0.98^{\mathrm{b}}$ & $72.2 \pm 19.2^{\mathrm{a}}$ \\
$200 \%$ SW & $0.23 \pm 0.08^{\mathrm{b}}$ & $1.86 \pm 0.69^{\mathrm{b}}$ & $3.14 \pm 2.52^{\mathrm{c}}$ & $22.2 \pm 19.2^{\mathrm{b}}$ \\
\hline
\end{tabular}

compared by using one way-ANOVA and Duncan's multiple range test with $p<0.05$.

\section{RESULTS}

\section{Long-term effects of salinity on fish}

Water $\mathrm{pH}$, temperature and osmolarity values are given in Table 2. $\mathrm{pH}$ and temperature were not changed during the experiment, but osmolarity was significantly increased with salinity increasethe in five treatment groups. Tilapia growth performance is shown in Table 3. Specific growth rate (SGR $0.95 \pm 0.18 \%$ per day) was the highest in $50 \%$ $\mathrm{SW}$; there were no significant differences among the first three groups. However, fish growth was significantly affected in the $200 \%$ SW (SGR $0.23 \%$ per day). SGR was lowered after 20 and 30 days in this treatment as seen in Figure 1. Weight gain and food intake were also the lowest in $200 \%$ SW (Table 3 and Figure 2). Weight gain decreased by $75 \%$ and food intake reduced by $78 \%$. Survival was high in the first four treatments $(72.2 \pm 19.2$ to $100.0 \pm 0.0 \%$ ). There were no significant differences among them. Mortality was highest in the $200 \%$ SW treatment $(22.2 \pm 19.2 \%)$.

\section{Short-term effects of salinity on fish}

Blood parameters of tilapia exposed to SW, 50, 100, 150 and $200 \%$ SW treatments are given in Table 4 . Sodium began to increase in the $100 \%$ SW $(158.5 \pm 8.5 \mathrm{mM})$ and elevated to $179.5 \pm 10.6$ and $184.0 \pm 13.9 \mathrm{mM}$ in 150 and $200 \%$ SW, respectively. Chloride increased from $100 \%$ SW $(139.5 \pm 8.0 \mathrm{mM})$ and reached $149.8 \pm 0.4$ and 149.7 $\pm 0.8 \mathrm{mM}$ in the 150 and $200 \%$ SW, respectively. However, potassium was unchanged (higher than 10 $\mathrm{mM})$. Glucose $(5.5 \pm 0.7$ to $7.1 \pm 2.4 \mathrm{mM})$ and total protein $(35.6 \pm 8.9$ to $50.4 \pm 5.3)$ also did not change.
Triglycerides declined from $2.7 \pm 0.7 \mathrm{mM}$ in SW to $1.9 \pm$ $0.3 \mathrm{mM}$ in $50 \% \mathrm{SW}$ and dropped to $1.1 \pm 0.3 \mathrm{mM}$ in $200 \%$ SW. Hematosomatic index and muscle water content values are presented in Table 5 . HSI was lower in $150 \%$ SW $(1.08 \pm 0.04 \%)$ and $200 \%$ SW (0.99\%) than SW $(1.35 \pm 0.11 \%), 50 \%$ SW $(1.24 \pm 0.06 \%)$ and $100 \%$ SW $(1.24 \pm 0.04 \%)$. Moisture decreased in $150 \%$ SW $(80.85 \pm 0.60 \%)$ and $200 \%$ SW $(80.19 \pm 0.64 \%)$; it was $81.68 \pm 0.02 \%$ in SW.

\section{DISCUSSION}

Many authors found that fishes grew better in brackish water than fresh water and sea water (or salt water) (Vonck et al., 1998; Imsland et al., 2001; Rubio et al., 2005; Resley et al., 2006; Arjona et al., 2009; Imsland et al., 2008; Kangombe and Brown, 2008; Kearney et al., 2008; Luz et al., 2008; Overton et al., 2008; Mylonas et al., 2009). Two earlier studies showed that fishes growth rate was higher in fresh water than salt water (Wang et al., 1997; Altinok and Grizzle, 2001). Some studies presented the growth and physiology of Mozambique tilapia acclimated to salt water (Morgan et al., 1997; Vonck et al., 1998; Fiess et al., 2007) but there is limited information about blue tilapia exposed to salt water.

Scientists have been trying to understand how salinity affects fish growth and metabolism and whether it changes fish energetics or not. There is an accepted hypothesis that isosmotic water decreases use of energy for osmoregulation compared to fresh water and salt water. This saved energy is used for growth. Some studies indicates that rising salinity in fresh water increases growth rate in tilapia; (from 5 to $10 \mathrm{ppt)}$ (Kangombe and Brown, 2008) (from 8 to 24 ppt) (Vonck et al., 1998) and some show that lowering salinity in marine enhances growth in turbot (from 32 to $15 \mathrm{ppt}$ ) 


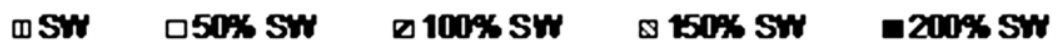

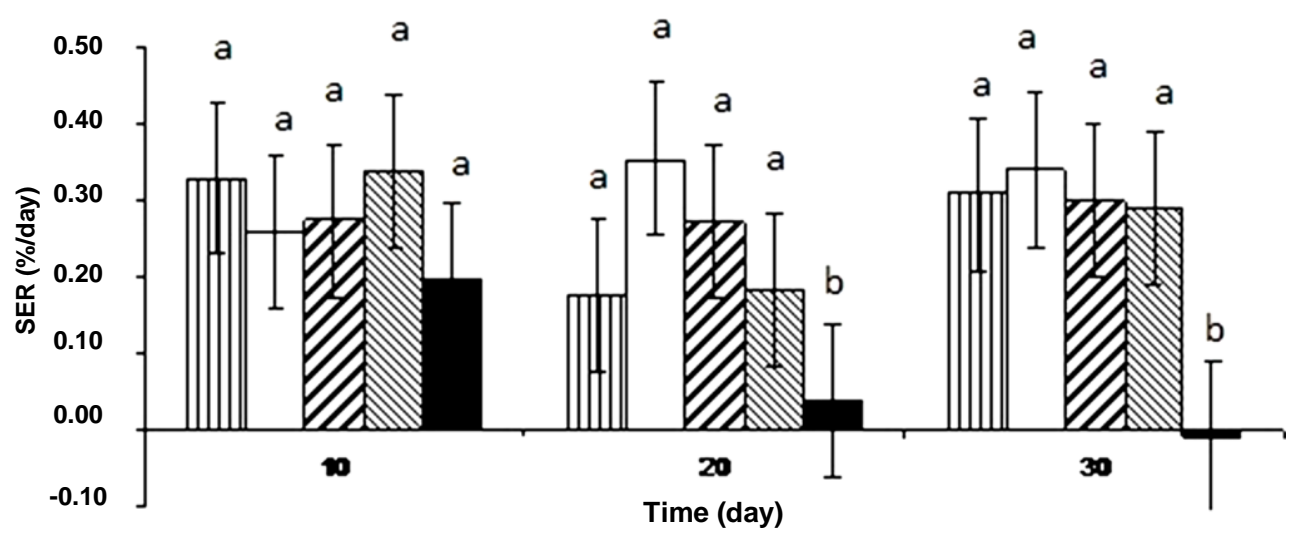

Figure 1. Tilapia specific growth rate (SGR) at five different salinities in 30 days.

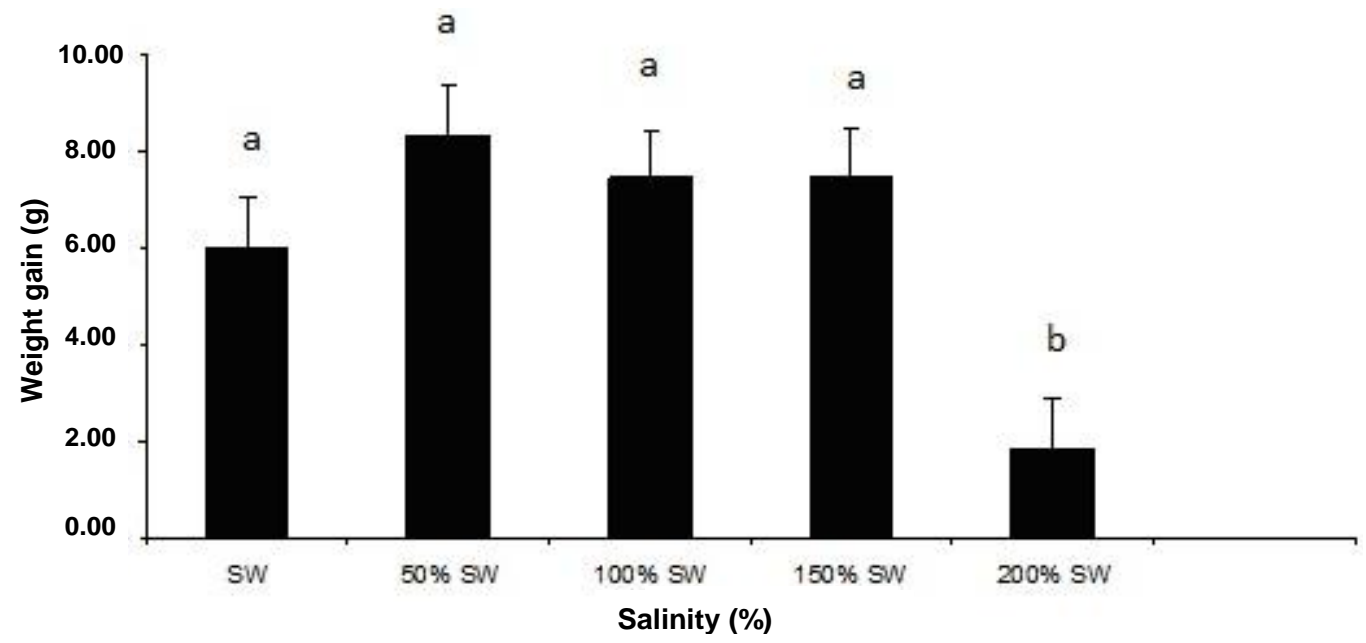

Figure 2. Tilapia weight gain at five different salinities in 30 days.

Table 4. Plasma sodium, chloride, potassium, glucose, total protein and triglycerides of tilapia in five different salinities (mean \pm SD) for 6 to $12 \mathrm{~h}$.

\begin{tabular}{ccccccc}
\hline Salinity & Sodium $(\mathbf{m M})$ & Chloride $(\mathbf{m M})$ & Potasssium $(\mathbf{m M})$ & Glucose $(\mathbf{m M})$ & Total Protein $(\mathbf{m M})$ & Triglycerides $(\mathbf{m M})$ \\
\hline SW & $144.2 \pm 6.4^{\mathrm{a}}$ & $124.5 \pm 9.8^{\mathrm{a}}$ & $>10$ & $6.1 \pm 3.1^{\mathrm{a}}$ & $44.8 \pm 5.8^{\mathrm{ab}}$ & $2.7 \pm 0.7^{\mathrm{a}}$ \\
$50 \% \mathrm{SW}$ & $146.0 \pm 6.2^{\mathrm{a}}$ & $124.8 \pm 6.7^{\mathrm{a}}$ & $>10$ & $7.0 \pm 0.7^{\mathrm{a}}$ & $50.4 \pm 5.3^{\mathrm{a}}$ & $1.9 \pm 0.3^{\mathrm{b}}$ \\
$100 \% \mathrm{SW}$ & $158.5 \pm 8.5^{\mathrm{b}}$ & $139.5 \pm 8.0^{\mathrm{b}}$ & $>10$ & $7.1 \pm 2.4^{\mathrm{a}}$ & $40.0 \pm 7.9^{\mathrm{b}}$ & $1.0 \pm 0.5^{\mathrm{c}}$ \\
$150 \% \mathrm{SW}$ & $179.5 \pm 10.6^{\mathrm{c}}$ & $149.8 \pm 0.4^{\mathrm{c}}$ & $>10$ & $6.8 \pm 1.3^{\mathrm{a}}$ & $35.6 \pm 8.9^{\mathrm{b}}$ & $1.1 \pm 0.5^{\mathrm{c}}$ \\
$200 \% \mathrm{SW}$ & $184.0 \pm 13.9^{\mathrm{c}}$ & $149.7 \pm 0.8^{\mathrm{c}}$ & $>10$ & $5.5 \pm 0.7^{\mathrm{a}}$ & $35.7 \pm 6.0^{\mathrm{b}}$ & $1.1 \pm 0.3^{\mathrm{c}}$ \\
\hline
\end{tabular}

(Imsland et al., 2008), in solea (39 to $15 \mathrm{ppt)} \mathrm{(Arjona} \mathrm{et}$ al., 2009), in sea bass (from 25 to 0 ppt) (Rubio et al., 2005), and in cobia (from 30 to 5 ppt) (Resley et al., 2006). Although a numbers of studies has been done on this area, there is a confusion to determine or calculate the cost of ion regulation. Earlier, energetic cost of osmoregulation was found very high (approximately 20 to $30 \%$ ) in rainbow trout and tilapia (Rao, 1968; Farmer and Beamis, 1969) and in catfish (50\%) (Furspan et al., 1984) in fresh water and salt water than in isosmotic waters. 
Table 5. Hematosomatic index and moisture of of tilapia in the five different salinities (mean \pm SD) for 6 to $12 \mathrm{~h}$.

\begin{tabular}{ccc}
\hline Salinity & HSI (\%) & Moisture (\%) \\
\hline SW & $1.35 \pm 0.11^{\mathrm{a}}$ & $81.68 \pm 0.02^{\mathrm{a}}$ \\
$50 \%$ SW & $1.24 \pm 0.06^{\mathrm{a}}$ & $81.05 \pm 0.49^{\mathrm{a}}$ \\
$100 \%$ SW & $1.24 \pm 0.04^{\mathrm{a}}$ & $80.85 \pm 0.60^{\mathrm{a}}$ \\
$150 \%$ SW & $1.08 \pm 0.04^{\mathrm{b}}$ & $80.19 \pm 0.64^{\mathrm{b}}$ \\
$200 \%$ SW & $0.99 \pm 0.01^{\mathrm{b}}$ & $80.52 \pm 0.83^{\mathrm{b}}$ \\
\hline
\end{tabular}

Energy expenditures for osmoregulation were supposed to be zero in isosmotic environments. However, latter on, required energy for ion regulation were found as $5.7 \%$ in rainbow trout and $12 \%$ (stardard metabolism) in flounder in SW (Kirschner, 1993; Imsland et al., 2003) and $<4 \%$ (total energy) in cutthroat (Morgan and Iwama, 1999) in FW and SW. Febry and Lutz (1987) indicated that methodology to estimate cost of osmoregulation should be controlled again. Further studies are needed to evaluate the accurate energy of osmoregulation in different salinities and determine optimal point for grow for the other species.

When environmental salinity changes, fish encounter morphological, biochemical and endocronological alterations in the acclimation time. These variations result in modifications in oxygen consumption and energy demands (Morgan and Iwama, 1991) although both marine fish ( $<5 \mathrm{ppt})$ and fresh water fish (10 to $15 \mathrm{ppt})$ demonstrated high growth performance in intermediate salinities (Boeuf and Payan, 2001). Every fish species has its special optimum salinity ranges for growth. For instance, grass could be reared at salinities up to $9 \mathrm{ppt}$ (Maceina and Shireman, 1980). Tilapia grew optimum in the range of 10 to 20 ppt (Suresh and Kwei-Lin, 1992). Turbot (Scophthalmus maximus) grew well at $18.5 \mathrm{ppt}$ and $21.8^{\circ} \mathrm{C}$ (Imsland et al., 2001). Shortfin glass eels (Anguilla australis) were reared well at $17.5 \mathrm{ppt}$ and 17.5 ${ }^{\circ} \mathrm{C}$ or 0 to $17.5 \mathrm{ppt}$ and $26.5^{\circ} \mathrm{C}$ (Kearney et al., 2008). Eurasian perch (Perca fluviatilis) showed optimum of growth rate at 0 to 8 ppt salinities (Overton et al., 2008). Shi drum (Umbrina cirrosa) had high growth rate at 10 ppt salinity (Mylonas et al., 2009). This study showed that optimum (point for blue tilapia was 12 ppt of salinity.

Two studies indicate that tilapia grow better in brackish water and sea water than fresh water (Liao and Chang, 1983; Watanabe et al., 1988). Kangombe and Brown (2008) reported that tilapia, Tilapia rendalli had a high growth rate at 5 to 10 ppt. Vonck et al. (1998) determined that tilapia, Oreochromis mossambicus growth rate increased at 8 to $24 \mathrm{ppt}$. In our study, blue tilapia grew best in $50 \%$ SW (12 ppt) (SGR $0.95 \pm 0.18 \%$ per day). Growth rate was lowest in the 200\% SW (24 ppt) (SGR $0.23 \pm 0.08 \%$ per day). Fish tolerate high level of salinity somehow but survival decreases as salinity increases. Kangombe and Brown (2008) reported that survival reduced with salinity increase. In the present study, survival was high in SW (8 ppt) and 50\% SW (12 ppt) treatments $(94.4 \pm 9.6$ to $100 \pm 0.0 \%)$. It decreased to $72.2 \pm 19.2 \%$ in $100 \%$ (16 ppt) and $150 \%$ SW (20 ppt) treatments. It was suprisingly low in $200 \%$ SW (24 ppt) treatment.

Salinity increase influences blood chemistry (sodium, potassium, chloride, glucose, total protein, triglycerides) as well. Sodium concentration was 144.2, 146.0, 158.5, 179.5 and $184.0 \mathrm{mM}$ in SW (8 ppt), 50\% SW (12 ppt), $100 \%$ SW (16 ppt), 150\% SW (20 ppt) and 200\% SW (24 ppt), respectively. Chloride concentration was 124.5, 124.8, 139.5, 149.8 and $149.7 \mathrm{mM}$ in SW (8 ppt), 50\% SW (12 ppt), 100\% SW (16 ppt), 150\% SW (20 ppt) and $200 \%$ SW (24 ppt), respectively. Sodium and chloride concentrations instantly increased in 100\% SW (16 ppt) and continued to increase in the upper salinities.

Morgan et al. (1997) reported that sodium and chloride ions showed similar patterns in mozambique tilapia. Sodium was about $136 \mathrm{mM}$ in the FW and rised to about $155 \mathrm{mM}$ and $170 \mathrm{mM}$ in ISO (12 ppt) and 75\% SW (25 ppt), respectively. Chloride increased around $165 \mathrm{mM}$ in the $75 \%$ SW while it was about $140 \mathrm{mM}$ in FW and ISO. Overton et al. (2008) also indicated that sodium and chloride concentrations increased at higher than 8 ppt. We found that potassium concentration remained unchanged in the fish exposed to the five different salinities. Potassium did not change significantly in mozambique tilapia, O. mossambicus (Morgan et al., 1997 ) in FW, ISO (12 ppt) and $75 \%$ SW (25 ppt), in perch, Perca fluviatilis (Overton et al., 2008) at 0 to 10 ppt and in shi drum, Umbrina cirrosa (Mylonas et al., 2009) at 4, 10, 40 ppt of salinity. Total protein and triglycerides and glucose in plasma are related to fish energy metabolism.

In the present study, there were no significant differences in the mean of plasma glucose concentration (around 5 to $7 \mathrm{mM}$ ) among the fish reared at all treatments. It may be due to the acclimatization of the fish to SW before the experiment started. Other studies (Morgan et al., 1997; Mylonas et al., 2009; Arjona et al., 2009) also found that glucose did not change during the salinity exposure. In this study, plasma triglycerides $(2.7 \pm$ $0.7 \mathrm{mM}$ at $8 \mathrm{ppt}$ ) significantly decreased in parallel with increase in salinity $(1.1 \mathrm{mM}$ at $24 \mathrm{ppt})$. Mylonas et al. 
(2009) found that triglycerides increased in shi drum at between 4 and $10 \mathrm{ppt}$ (3.1 to $7.1 \mathrm{mM}$, respectively), but it decreased at $40 \mathrm{ppt}(4.7 \mathrm{mM})$. On the contrary, Arjona et al. (2009) reported that plasma triglycerides increased in sole, Solea senegalensis. It reached from 2.8 to $10.7 \mathrm{mM}$ at between 15 and 39 ppt.

Our findings show that high salinity caused alterations in muscle tissues, also. Hepatosomatic index and muscle moisture were significantly decreased in $150 \%$ SW and $200 \%$ SW. It reduced by 1.08 and $0.99 \%$ in $150 \%$ SW (20 ppt) and $200 \%$ SW (24 ppt), respectively, while it was by $1.35 \%$ in SW. On the other hand, HSI (mean 1.1\%) did not change in sole (Arjona et al., 2009) at 15, 25, 39 ppt and in goldfish (Luz et al., 2008) at 0 to 10 ppt. Muscle water content showed a similar trend with HSI. It was $81.68 \%$ in the SW, but declined by 80.19 and $80.52 \%$ in 150 and $200 \%$ SW, respectively. Muscle moisture reduced in grass carp (Maceina and Shireman, 1979), in Mozambique tilapia at 10 to 20 ppt (Lee et al., 2005), in goldfish (Luz et al., 2008) at 10 ppt of salinity. However, muscle moisture (around 79 to $82 \%$ ) did not change at 0 to 10 ppt of salinity (Overton et al., 2008).

Vertebrates have $9 \mathrm{~g} / \mathrm{L}$ salt and $\mathrm{pH} 7.4$ in their blood. About $77 \%$ of this salt consists of sodium and chloride ions. The remainder (23\%) is composed of bicarbonate, potasium and calcium ions. Especially, sodium and potassium have an important role in heart, nerve and muscle functions. When fish starts losing salt from blood, higher energy is needed to replace it. It causes heart failure, nerve and muscle spasms. If the water has high bicarbonate alkalinity and calcium hardness, fish can be transferred easily from freshwater to seawater or from seawater to freshwater. It is reported that the ideal water condition for fish transportion is 100 to $200 \mathrm{mg} / \mathrm{L}$ as $\mathrm{CaCO}_{3}$ of bicarbonate alkalinity, 125 to $250 \mathrm{mg} / \mathrm{L}$ as $\mathrm{CaCO}_{3}$ of calcium hardness, $\mathrm{pH}$ of 7 to 8 , and $8 \mathrm{~g} / \mathrm{L}$ salt (Wurts, 1995). It also indicates that water having high calcium concentration sedates fish by decreasing ion loss (Wurts, 1998).

These values show that our water source has a characteristic ideal water condition for fish transport. The water source had high level of monovalent and divalent ions. It may be an ideal water at the level of isosmotic salinity for transport. Nowadays, brackish water is encouraged to be use in aquaculture because of the competitions between land and water use in agriculture. There are some fish species that have high potential for culturing because of high salinity tolerance capacity such as sea bream, sea bass, mullet, turbot, and tilapia. Especially, most of the tilapia species have high salinity tolerance capacity. Mozambique tilapia, O. mossambicus (42 ppt) (Stickney, 1986; Wang et al., 1997) has higher salinity tolerance for growth than blue tilapia, Oreochromis aureus and nile tilapia, Oreochromis niloticus (20 ppt) (Nugon, 2003). Hybrids (20 to $30 \mathrm{ppt)}$ (Avella and Doudet, 1996) that occurred by crossbreeding between different tilapia species have high tolerance to salinity than their parents.

\section{Conclusion}

The present results show that environmental salinity influence the growth and metabolism of tilapia, $O$. aureus for 30 days. Optimum condition for farming tilapia is 12 ppt (isosmotic environments). Fishes exposed to $24 \mathrm{ppt}$ of salinity were sturdily affected. The ability of tilapia to use environments at low salinities, up to isosmotic levels, makes it to be the candidate for growth in lagoons and estuaries. Thus, tilapia, $O$. aureus can be an alternative species in marine aquaculture.

\section{ACKNOWLEDGEMENT}

This work was funded by the Scientific Reseach Fundation of Adnan Menderes University with no. ZRF 10009.

\section{REFERENCES}

Altinok I, Grizzle JM (2001). Effects of brackish water on growth, feed conversion and energy absorption efficiency by juvenile euryhaline and freshwater stenohaline fishes. J. Fish Biol. 59: 1142-1152.

Arjona FJ, Vargas-Chacoff L, Ruiz-Jarabo I, Gonçalves O, Pascoa I, Martin Del Rio MP, Mancera JM (2009). Tertiary stress responses in Senegalese sole (Solea senegalensis Kaup, 1858) to osmotic challenge: Implications for osmoregulation, energy metabolism and growth. J. Aquacult. 287: 419-426.

Avella M, Doudet T (1996). Physiological adaptation of Oreochromis niloticus and $O$. aureus to salinity, p. 461-470. In RSV Pullin, J. Lazard, M. Legendre, JB Amon Kothias and D. Pauly (eds) The Third International Symposium on Tilapia in Aquaculture. ICLARM Conf. J. Proc. 41: 575.

Boeuf G, Payan P (2001). How should salinity influence fish growth? Comp. Biochem. Physiol. C. 130: 411-423.

Boyd CE (1990). Water Quality in Ponds for Aquaculture. Auburn University, Birmingham, pp. 138-142.

Boyd CE, Tucker CS (1998). Pond Aquaculture Water Quality Management. Kluwer Aademic Publishers, Nowell, p. 97.

Farmer GJ, Beamis FWH (1969). Oxygen consumption of Tilapia nilotica in relation to swimming speed and salinity. J. Fish. Res. Board Can. 26: 2807-2821.

Febry R, Lutz P (1987). Energy partitioning in fish: The activity-related cost of osmoregulation in a euryhaline cichlid. J. Exp. Biol. 128: 6385.

Fiess JC, Kunkel-Patterson A, Mathias L, Riley LR, Yancey PH, Hirano T, Grau EG (2007). Effects of environmental salinity and temperature on osmoregulatory ability, organic ormolytes, and plasma hormone profiles in Mozambique tilapia (Oreochromis mossambicus). Comp. Biochem. Physiol. Part A 146: 252-264.

Furspan p, Prange HD, Greenwald L (1984). Energitics and osmoregulation in the catfish, Ictalurus nebolosus and $I$. punctatus. Comp. Biochem. Physiol. A 77: 773-778.

Imland AK, Gunnarsson S, Foss A, Stefansson SO (2003). Gill Na+ $\mathrm{K}^{+}$ATPase activity, plasma chloride and osmolality in juvenile turbot (Scophthalmus maximus) reared at different temperatures and salinities. Aquaculture 218: 671-683.

Imsland AK, Foss A, Gunnarsson S, Berntssen MHG, FitzGerald R, Bonga SW, Ham EV, Naevdal G, Stefansson SO (2001). The 
interaction of temperature and salinity on growth and food conversion in juvenile turbot (Scophthalmus maximus). Aquaculture 198: 353367.

Imsland AK, Gustavsson A, Gunnarsson S, Foss A, Arnason J, Arnarson I, Jonsson AF, Smaradottir H, Thorarensen H (2008). Effects of reduced salinities on growth, feed conversion efficiency and blood physiology of juvenile Atlantic halibut (Hippoglossus hippoglossus L.). Aquaculture 274: 254-259.

Kangombe J, Brown JA (2008). Effect of salinity on growth, feed utilization and survival of Tilapia rendalli under laboratory conditions. J. Appl. Aquaculture 20: 256-271.

Kearney M, Jeffs A, Lee $P$ (2008). Effects os salinity and temperature on the growth and survival of New Zealand shortfin, Anguilla australis, and longfin, A. dieffenbachii, glass eels. Aquacult. Res. 39:1769-1777.

Kirschner LB (1993). The energetics of osmotic regulationin ureotelic and hypoosmotic fishes. J. Exp. Zool. 267:19-26.

Lee AC, Lin CR, Chen SM (2005). Acclimation of mozambique tilapia (Oreochromis mossabicus) to salinity changes alters protein content of larvae and their liver and kidney. Aquat. Res. 6: 936-939.

Liao C, Chang LS (1983). Studies on feasibility of red tilapia culture in saline water. Proceedings of the First International Symposium on Tilapia in Aquaculture, pp. 524-533.

Luz RK, Martinez-Alvarez RM, DePedro N, Delgado MJ (2008). Growth, food intake regulation and metabolic adaptations in goldfish (Carassius auratus) exposed to different salinities. Aquaculture 276: 171-178.

Maceina MJ, Shireman JV (1979). Grass carp: effects of salinity on survival, weight loss, and muscle tissue water content. Prog. Fish Cult. 41: 69-73.

Maceina MJ, Shireman JV (1980). Effects of salinity on vegetation consumption and growth in grass carp. Prog. Fish Cult. 42: 50-53.

Mommsen T (1998). Growth and metabolism. In: Evans D (ed) The Physiology of Fishes, Second edititon, CRC Press, Boca Raton, pp. 65.

Morgan JD, Iwama GK (1999). Energy ost of transport in isolated gills of cuttroat trout. Am. J. Physiol. 277: 631-639.

Morgan JD, Sakamoto T, Grau EG, Iwama GK (1997). Physiological and Respiratory responses of the Mozambique tilapia (Oreochromis mossambicus) to salinity acclimation. Comp. Biochem. Physiol. A. 117: 391-398.

Mylonas CC, Pavlidis M, Papandroulakis N, Zaiss MM, Tsafarakis D, Papadakis IE, Varsamos S (2009). Growth performance and osmoregulation in shi drum (Umbrina cirrosa) adapted to different environmental salinities. Aquaculture 287: 203-210.
Nugon RW (2003). Salinity tolerance of juveniles of four varieties of tilapia. MSc. Thesis, Louisiana State University, USA, pp. 18-20.

Overton JL, Bayley M, Paulsen H, Wang T (2008). Salinity tolerance of cultured Eurasian perch, Perca fluviatilis L.: Effects on growth and survival as a function of temperature. Aquaculture 277: 282-286.

Popma T, Masser M (1999). Tilapia life history and biology. SRAC Publication, p. 283.

Rao GMM (1968). Oxygen consumption of rainbow trout (Salmo gardnerI) in relation to activity and salinity. Can. J. Zool. 46: 781-786.

Resley MJ, Webb KA, Holt GJ (2006). Growth and survival of juvenile cobia, Rachycentron canadum, at different salinities in a recirculating aquaculture system. Aquaculture 253: 398-407.

Rubio VC, Sanchez-Vazquez F, Madrid JA (2005). Effects of salinity on food intake and macronutrient selection in European sea bass. Physiol. Behav. 85: 333-339.

Suresh AV, Kwei-Lin C (1992). Tilapia culture in saline waters: A review. Aquaculture 106: 201-226.

Stickney RR (1986). Tilapia tolerance of saline water: A review. Prog. Fish Cult. 48:161-167.

Vonck APMA, Wendelaar Bonga SE, Flik G (1998). Sodium and calcium balance in mozambique tilapia, Oreochromis mossambicus, raised at differnt salinities. Comp. Biochem. Physiol. A. 119: 441-449.

Wang J, Lui H, Po H, Fan L (1997). Influence of salinity on food consumption, growth and energy conversion efficiency of common carp (Cyprinus carpio) fingerlings. Aquaculture 148: 115-124.

Watanabe WO, Ellingson LJ, Wicklund RI, Olla BL (1988). The effects of salinity on growth, food consumption and conversion in juvenile monosex male Florida red tilapia. In Pullin RVS, Bhukaswan T, Tonguthai K, Maclean JL (eds). The Second International Symposium on Tilapia in Aquaculture. ICLARM Conference Proceedings 15. Department of Fisheries, Bangkok, Thailand and International Center for Living Aquatic Resources Management, Philippines, pp. 515-523.

Wurts WA (1995). Using salt to reduce handling stress in channel catfish. World Aquacult. Manage. 29: 80-81.

Wurts WA (1998). Why can some fish live in freshwater, some in salt water, and some in both? World Aquacult. Manage. 29(1): 65. 